\title{
IAMJ
}

INTERNATIONAL

AYURVEDIC

MEDICAL JOURNAL

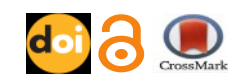

Review Article

ISSN: 2320-5091

Impact Factor: 6.719

\section{AN AYURVEDIC APPROACH TOWARDS POSTMENOPAUSAL OSTEOPOROSIS - A REVIEW}

Pradnya Vijay Shirke

M.S. (Prasutitantra \& Streerog)

D.Y. Patil College of Ayurved and Research Center, Pimpri, Pune, 411018, Maharashtra, India

Corresponding Author: pradnyashirke2@gmail.com

https://doi.org/10.46607/iamj.3009012021

(Published online: January 2021)

Open Access

(C) International Ayurvedic Medical Journal, India 2021

Article Received: 22/12/2020 - Peer Reviewed: 28/01/2021 - Accepted for Publication: 06/01/2021

(D) Check for updates

\section{ABSTRACT}

India is the second largest country in the world regarding population. As the life expectancy has increased, the population of postmenopausal women is also increased. Hence the problems associated with increasing age are increased. The studies of last two decades suggest that women in menopausal age report more physiological and psychological problems. Osteoporosis is one among them. Osteoporosis or porous bone is a worldwide problem, characterized by low bone mass and structural deterioration of bone tissue, leading to bone fragility and an increased risk of fractures. In modern science treatment available for menopausal symptoms is mainly symptomatic and has some adverse effects too. In Ayurveda we cannot find the name of this disease, but signs and symptoms of AsthiKshaya are found quite similar to osteoporosis. The function of dhatu is dharana (To maintain the structure) of the body. Among all dhatus, asthidhatu is responsible for maintenance of structural framework of the body. It shapes the body and protects the vital organs. Acharya Charaka in Sutra Sthan has explained the concept of osteoporosis. Aggravation of Vata is a main cause of Asthi-Kshaya and so it is mentioned as a Vata related disorder in Samhitas. Principle of treatment mentioned in Charak Samhita is as, "Samanagunabhyaso Hi Dhatunaam Vruddhi Karanam". According to it, things, which contain similar properties to a particular Dhatu of body, can be helpful to increase that one Dhatu. So Vatashamak medicines, diet, exercise having similar properties to Asthi Dhatu, Panchakarma, Rasayana can be very effective to promote bone cells in body. This study is an attempt to understand Nidana panchaka of this disease, and its holistic management in context of Ayurveda. 
Keywords: Menopause, Rajonivrutti, Osteoporosis, Asthikshaya

\section{INTRODUCTION}

In the era of information \& technology, women are dynamic and having a multi-dimensional attitude. But Indian woman still has a tendency to ignore her health issues. While looking after the family, her own health is always compromised. Though Menopause is a natural and inevitable event as a part of the normal process of aging, it is becoming a major health issue in recent years, in developed as well as developing countries like India. It is a more complex phase of old age in women than men. Women in this age group have special needs. However, the public healthcare system does not acknowledge the special needs of women. The unpleasant change experienced by women during this phase is termed as menopausal syndrome which is characterized by psychosomatic disturbances. Hormone replacement therapy (HRT) is the conventional treatment being practiced for it; however, HRT is associated with many side effects. In postmenopausal women, tendency to fall into osteoporosis is very high due to hormonal insufficiencies. Women $\geq 50$ years of age have a four times higher rate of osteoporosis and a two times higher rate of osteopenia, and they tend to have fractures 5 10 years earlier compared with men. ${ }^{[1]}$

Though different treatment modalities like HRT, Calcium \& Vit-D supplements are commonly used, there is no treatment which has satisfactory improvement without side effects. Due to some adverse effects and lacunae of synthetic drugs, there is a need of finding out better remedy for the management of osteoporosis. Ayurveda seems to be effective in addressing the above-mentioned limitations of the conventional therapies.

Postmenopausal Osteoporosis- It is the second most common metabolic bone disease in India. ${ }^{[2]}$ In osteoporosis, the bone mineral density (BMD) is reduced, bone microarchitecture deteriorates, and the amount and variety of proteins in bone are altered.

World Health Organization defines Osteoporosis as "Progressive systemic skeletal disease characterized by low bone mass and micro architectural deterioration of bone tissue, with a consequent increase in bone fragility and susceptibility to fracture". ${ }^{[3]}$ Not only does it give rise to morbidity but also markedly diminishes the quality of life of women after menopause. ${ }^{[4]}$ It is called a silent disease because it can develop gradually over many years without causing any symptoms.

As per modern medicines there are two factors which are important in the disease osteoporosis, first is peak bone mass and second is the process of remodeling. It is a constant phenomenon which is always happening in the bone. When the bone resorption supersedes bone formation then the bone becomes weak and the chances of osteoporosis increase. Bone remodeling is the primary function of osteoblasts (responsible for bone formation) and osteoclasts (responsible for bone resorption), while other hormones (esp. estrogen), growth factors, along with cytokines, play a regulatory role in maintaining bone homeostasis. ${ }^{[5-8]}$

Menopause is a natural, hormone (estrogen) deficient state that occurs at the age of 45-55 years. In menopause estrogen gradually decreases which causes increase in bone reabsorption and decrease in the deposition of new bone that normally takes place in weightbearing bones which leads to accelerated bone loss. ${ }^{[9]}$ Acute ovarian estrogen deficiency (due to the increased osteoclast activity) leads to the depletion of calcium, collagen and proteins from bone, with the resultant increase in bone porosity. ${ }^{[10-11]}$ Bone resorption increases by $90 \%$, whereas bone formation increases by only $45 \%$. This imbalance in bone resorption and remodeling leads to accelerated bone loss. ${ }^{[12]}$

Some studies have shown the influence of estrogens on bone mass in premenopausal state. There is positive association between bone mass and parity in premenopausal women as per some studies. Some studies have stated the association of oral contraceptive use with higher bone mass in some women. A number of hypoestrogenic states in premenopausal women are associated with reduced bone mass. Amenorrhea in female athletes and ballet dancers is associated with low bone mass and fracture risk ${ }^{[13]}$ indicates the presence of osteoporosis. ${ }^{[14]}$ Standard therapies include anti- 
resorptive drugs that decrease bone loss, e.g., bisphosphonates, calcitonin, selective estrogen receptor modulators, calcium and anabolic agents that increase bone formation. ${ }^{[15]}$

\section{Rajonivrutti (Menopause) and Asthikshaya (Osteo- porosis) -}

Ayurveda links menopause with aging, i.e., Jarawastha of body. ${ }^{[16]}$ As age advances natural declining in quality and quantity of all Dhatus (Kshaya) occurs by the result of increased Vata. Bhava Prakasha has described 80 types of Vata rogas and Rajonasaas (loss of menstruation) is one among them. ${ }^{[17]}$

Ayurveda has emphasized on Samata and Vishamata of dhatu while mentioning the definition of health as well as disease. ${ }^{[18]}$ State of equilibrium of all dhatus is health and Vaishyam i.e. disturbance in this equilibrium is called disease. So, any of increase (Vruddhi) or decrease (Kshaya) in dhatu can be a disease condition. Asthi kshaya is a condition in which there is kshaya (degeneration) of Asthi dhatu. Asthi kshaya may be co-related to osteopenia/osteoporosis where there is a decrease in the bone tissue.

Asthidhatu is supposed to be seat of vata. Both of these are having asharaya-Asharayee Bhav relationship between them. Any causative factor which aggravates vata causes harmful effect on Asthidhatu. For all types of kshayas Charak has explained common causative factors which can be considered as causative factors for Asthi kshaya also. ${ }^{[19]}$ It is clear from above mentioned reasons that in treating Asthikshaya, vata aggravation is to be corrected.

\section{Nidan (Etiology)}

The etiological factors for Asthikshaya are not found separately in the samhitas. We need to understand the etiological factors for Asthikshaya on the principles of ashrayashrayi Bhavas.

1) Sahaja Hetu (Genetical cause)

a) Vitiation of Beeja (eggs or sperms), Beejabhaga (genes), Beejabhagavayava: It may be considered as a causative factor for weakness in Asthi Dhatu in the offspring. ${ }^{[20,21]}$

b) Pitrija Bhava: in Garbhavkranti it is mentioned that Pitrija Bhava is responsible for formation of Asthi
Dhatu. Therefore, any abnormality in Pitrija Bhava can be a cause of improper Asthi Dhatu formation. ${ }^{\text {[22] }}$

2) Jataja Hetu (Congenital cause) ${ }^{[23,24]}$

Asthidhatu is supposed to be seat of Vatadosha. Both of these are having Asharaya-Asharayee Bhava relationship between them. So, factors aggravating Vata affects Asthi dhatu and, which lead to imbalance of Asthi Dhatu proportion in body. ${ }^{[25]}$

a) Intrauterine life- if pregnant lady doesn't follow the Garbhini Paricharya (do's and don'ts in pregnancy), if she consumes excessive Vata aggravating food, then Asthidhatu of her offspring may get affected, causing Asthivikruti. ${ }^{26]}$

b) Factors causing aggravation of vata-

i) Excessive intake of food having Ruksha Laghu, Sheeta, Vishad, Chala Guna; Katu, Tikta, Kashya Rasa; less intake of Snigdha, Guru Guna Ahara; and Ksheera Dravya like Ksheera, Ghrita.

ii) Faulty dietary habits like - Langhana -AnashanAlpashana (frequent fasting and inadequate food intake), Ativyayama (Excessive exercise), Ativicheshta (exertion), Avyayama (Sedentary life style), Divasvapna (sleeping in daytime), Dukhshaiyasana (discomfort bed), Sheeghrayana (excessive travelling), Atiprajagarana (inadequate night sleep), Patana- Abhighata (Injuries leading to fracture), Chinta (worries), Shoka (agony), Krodha (anger), Bhaya (fear), etc.

Strotodushti-There are two causes for vitiation of $A s$ thivaha Srotas; one is excessive exercise causing friction and inflammation of bones and second one is intake of food that aggravates Vata. ${ }^{\text {[27] }}$

3) Swabhavaja Hetu: Generally, women have genetically low bone mass than men. So postmenopausal osteoporosis is peculiar in women. In Ayurvedic texts too, references regarding to this are given at various places. Acharyas have mentioned some special characteristics of women contrary to men, which are considered under Streekara Bhava. ${ }^{28,29]}$

a) Samhanana: Samhanan is proper distribution of asthi (quality and quantity wise). It is examined by qualitative and quantitative wise proper distribution of asthi dhatu. Hence asamhanana is related to asthi dhatu that is weaker in female as compared to male. ${ }^{[30]}$ 
b) Shaithlya indicates laxity of joints and other body parts.

c) Mardava denotes softness of all body parts.

d) Acharya Kashyapa has described the characteristics of danta (teeth) in male and female while explaining dentition. Dentition in girls is less painful than boys as their teeth are mridu and sushira in constitution by nature.

All these facts show that Asthi Dhatu is naturally weak in women as compared to men. Therefore, in women after Rajonivritti, where kshaya of all Dhatus becomes fast, Asthi Dhatu is markedly affected because of already having weak constitution.

4) Kaalaj: During Jaravastha aggravation of Vata and natural decline in quantity and quality of all dhatus occur which leads to degeneration in bones.

Probable Etio-Pathogenesis (Samprapti) of the Postmenopausal Osteoporosis:

Samprapti of asthikshaya has not been explained directly anywhere in Ayurvedic samhitas. Considering all the etiological factors explained under vatavyadhi, asthikshaya pathogenesis can be explained in following way.

\section{Etiological Factors:}

Dosha: Rajonivritti-Janya Asthi- Kshaya is a disease occurring in aging phase Vata Dosha is a main cause for its occurrence. Simultaneously Kshaya of Kapha occurs along with it.

Dushya: This is the disease of Asthidhatu and its Mala -Nakha and Kesha. Among all of these main dushya Asthidhatu it is most affected.

Strotas: Asthivaha Strotas get affected. So nutritive factors are not supplied to Asthi Dhatu through Asthi Vaha Srotas.

Agni: In the pathogenesis of Asthi Kshaya all three agni, i.e. Jatharagni, Bhutagni and Dhatwagni are responsible.

The vitiation of Jatharagni leads to improper digestion of the food resulting in the production of Ama rasa, which contains very less nutrients or may totally be devoid of nutrients leading to improper nourishment of the Asthi resulting in Asthi kshaya.
In Jaravastha, vitiated Jatharagni also affects both Dhatvagni and Bhootagni which leads to improper formation of Asthidhatu.

Manasik Avastha: The involvement of the psyche can also be considered in the etiopathogenesis of this disease, because body and mind have close association with each other. Charaka opines that the Sharirika Roga (somatic diseases) and Manasika roga (psychic diseases) have inter-relationship. ${ }^{[31]}$

Samprapti: Vitiation of vata is the main factor responsible for Asthi kșhaya. More intake of Vataja AharaVihara and less consumption of Snigdha Prakriti Ahara especially by menopausal women cause aggravation of Vata. This leads to provocation of vata and this vitiated vata fills in the channels which are devoid of unctuousness and vitiate them further leading to the stronger provocation of its own. The factors which have considered under Swabhavaja Nidana as Streekara Bhava-Asamhanana together with Sahaja Nidana i.e. Beeja Duṣtti and Pitrija Bhava Dushti cause vitiation of Asthi dhatu.

Proper functioning of jatharagni, bhutagni and dhatwagni is essential for proper nourishment of dhatu which ultimately maintains quality and quantity of Dhatu. When the functioning of jatharagni becomes improper, Aam (indigestion) is formed, which can further cause strotorodh (obstruction in channels) leads to improper nourishment of asthi resulting in asthikshaya. Improper functioning of Dhatwagni leads to the deformity in the transformation of dhatuposhakanshu (Dhatu specific nutrients) into sthayi dhatu, resulting in dhatu vikriti. As asthi is composed of parthiv, tejas and vayu mahabhuta. Any functional deficit in any of these bhutagni lead to nutritional deficit resulting in asthikshaya.

\section{Sign \& Symptoms (Rupa)}

In the initial stage, Osteoporosis is totally asymptomatic as low bone mass itself doesn't cause any symptoms and so it is called as the "silent thief".

The main symptoms of Asthikshaya described in different samhita are asthibheda (fractures), asthishula (pain). Generally, when dhatu is affected its upadhatu and mala is also affected; hence the symptoms like kesha vikara (disorders of hair), nakha vikara 
(disorders of nails), smashru vikara (disorders of moustache) danta vikara and paata (disorders of teeth) sandhi shaithilya (pain in joints), rukshata (dryness) are also seen in Asthikshaya.

\section{Management}

Ayurveda treatment visualizes the human body as a single unit and the approach of the treatment has been always holistic. The treatment of asthikshaya includes $n i-$ dana parivarjana (Avoidance of etiological factors), shodhana (Bio purification), shamana (Palliative treatment), rasayana (Rejuvenation), pathyapathya (Proper diet).

\section{Nidana Parivarjana (Avoidance of etiological fac- tors):}

Primary principle in Ayurveda is to avoid the causative factors. The individual suffering from Asthi kshaya must avoid excessive indulgence in etiological factors responsible for vitiation of Vata, vitiation of Asthivaha strotas.

\section{Shodhana Chikitsa (Biopurification):}

It is indicated in bahudoshaavastha. Vaghbhatta had mentioned this in asthikshayachikitsa. ${ }^{[32]}$ Acharya charak has given the similar line of treatment for asthi pradoshaja vikara which includes panchakarma, especially basti which contains kshira, ghrita and tikta dravya. ${ }^{[33]}$

3. Shamana Chikitsa (Palliative Treatment): The main aim of Ayurvedic therapy in asthigatvata includes vatashamak (asthi is the seat of vata), Tarpak and Brihman treatment. Acharya Sushruta has described the Chikitsa Sutra of Asthi kshaya along with the Chikitsa of all 18 types of kshaya. The dravya which are of Swayoni i.e. similar to the respective dhatu are to be used for the treatment of the respective dhatu kshaya. ${ }^{[34]}$ Here, in Asthi kshaya, dravya similar to Asthi dhatu should be used. This is based on the Samanya Siddhanta. Use of Taruna Asthi increases the Asthi dhatu. ${ }^{[35]}$ Use of Asthi in its transformations i.e. Bhasma (ash) will also increase Asthi dhatu. Keeping this principle in mind many preparations are used in Ayurveda Preparations like Ajasthi bhasma, Kurma prishthasthi bhasma, Mrigashringa Asthi bhasma, Asthi bhasma of other animals etc.
4. Rasayana: Rasayana is a boon for menopausal women and proves very good effects on female in menopausal period. Rasayan drugs like Shatavari, Vidari, and Kumari reduce fatigue and vaginal dryness. For psychological symptoms, like irritability, anxiety, or depression, there are very effective drugs like Brahmi, Jyotishmati, Shankhapushpi can be given.

Osteoporosis is the disease of Jaravastha. Jara is classified under Svabhavaja Vyadhi which becomes Yapya by Rasayana treatment. Hence for preventing Asthi Kshaya, dravya that is Tikta in Rasa, Snigdha in Guna Rasayana Prabhava and possessing should be selected. Some commonly used rasayan drugs are Dwitiya Brahma Rasayana, Tritiya Triphala Rasayana, Chathurtha Triphala Rasayana, Chyavanaprasha Rasayana, Shatavari Rasayana, Shilajatu Rasayana etc.

Role of Basti- in Ayurveda Basti treatment is considered as a prime treatment modality. ${ }^{[36]}$ Lipid soluble drugs are absorbed by passive diffusion and some of the active ingredient are absorbed through active transport. The bioavailability of the drugs is higher when given as Basti. Modern medical science also suggests some of the nutrient enemas meant for the nutrition of the body, where absorption of carbohydrate, fat and protein is mentioned. ${ }^{[37]}$

Some popular oil preparations can be effective are Kshirabala Taila, Chandanabala Lakshadi Taila, Dhanvantara Taila, Balaguduchyadi Taila, Balashwagandhadi Taila, Lakshadi Taila, Mahalakshadi Taila.

\section{CONCLUSION}

Menopause is a phase characterized by a cluster of physical and psychological changes. The Postmenopausal period is associated with significant incidences of age-related medical conditions like cardiovascular diseases, fractures and osteoporosis. Osteoporosis can be covered under Asthi kshaya. Pathogenesis of Asthi kshaya is a complex mechanism and hence no single drug is advisable to reverse the pathogenesis. It requires a 'Holistic approach' to manage Asthi kshaya effectively. Early diagnosis, prevention and intervention should be the protocol to treat the disease. Treatment should be planned considering all the factors like Dosha, Dushya, Kala, Bala, Agni etc. of the patients. 
Thus, Ayurveda can play a major role to treat osteoporosis.

\section{REFERENCES}

1. Alswat, Khaled A. "Gender Disparities in Osteoporosis." Journal of clinical medicine research vol. 9,5 (2017): 382-387. doi:10.14740/jocmr2970w

2. API Textbook of medicine by Siddharth N Shah, The Association of Physicians of India, Mumbai, 8th edition 2008, volume 1, page no-226)

3. World Health Organization. Assessment of fracture risk and its application to screening for Postmenopausal Osteoporosis. Geneva, WHO, 1994.

4. Sambrook PN, Dequiker J, Rasp HH, Metabolic Bone Disease, Report of a WHO Study Group, Assessment of Fracture Risk and its Application to Screening for Postmenopausal Osteoporosis. WHO Technical Report Series, Geneva; 1994:

5. Ernst M, Heath JK, Schmid C, et al. Evidence for direct effect of estrogen on bone cells in vitro. J Steroid Biochem 1989; 34: 279-284.

6. Schot LPC, Schuurs AHWM. Sex steroids and osteoporosis: Effects of deficiencies and substitutive treatments. J Steroid Biochem Mol Biol 1990; 37: 167-182.

7. Blair HC, Schlesinger PH, Ross FP, et al. Recent advances toward understanding os teoclast physiology. Clin Orthop 1993; 294: 7-22.

8. Manolagas SC, Jilka RL. Bone marrow, cytokines, and bone remodeling: emerging insights into the pathophysiology of osteoporosis. N Engl J Med 1995; 332: $305-$ 311.

9. Khosla S, Riggs BL. Pathophysiology of age-related bone loss and Osteoporosis. Endocrinology and Metabolism Clinics of North America 2005;34(4):1015-30.

10. Nguyen T, Sambrook P, Kelly P, et al. Prediction of osteoporotic fractures by postural instability and bone density. BMJ 1993; 307: 1111-1115.

11. Cummings SR, Black DM, Nevitt MC, et al

12. Khosla S, Riggs BL. Pathophysiology of age-related bone loss and osteoporosis. Endocrinology and Metabolism Clinics of North America 2005;34(4):1015-30.

13. Baker E, Demers L. Menstrual status in female athletes: correlation with reproductive hormones and bone density. Obstet Gynecol; 1988, 72: 683-687,

14. Pratap Kumar et al., Jeffcoate's principles of Gynaecology; 7th Edit., Jaypee Brothers, 2008, Chap. 53- Menopause, P.872.
15. Faldu KG, Duvva H, Shah JS, Shah PV, Patel SS. An ayurvedic proprietary herbal preparation, Calci-7, prevents ovariectomy-induced osteoporosis in rats. Ayu. 2016;37(3-4):250-255. doi:10.4103/ayu. AYU4_1

16. Charak: Charak samhita with Ayurveda dipika commentary of chakrapanidatta, chaukhamba, Sanskrit sansthan 5th edition, Varansi

17. Bulusu sitaram English translation of Bhava Prakash

18. Agnivesha. Charaka Samhita. Yadavji Trikamji Acharya, Editor. Varanasi: Chaukhamba Surbharati Prakashan; 2013. Sutra Sthana 9/4.

19. Agnivesa, Charaka, Dridhabala, Charaka Samhita, Sutra Sthan Kriyantahasirsiya Adhayay 17/76- 77 edited by Gangasahay Pandey 1st volume, Chaukumba Sanskrit Sansthan, Varanasi. 2006; P.352

20. Agnivesha. Charaka Samhita. Yadavji Trikamji Acharya, Editor. Varanasi: Chaukhamba Surbharati Prakashan; 2013. Shareer Sthana 3/17, P.315

21. Agnivesha. Charaka Samhita. Yadavji Trikamji Acharya, Editor. Varanasi: Chaukhamba Surbharati Prakashan; 2013. Shareer Sthana 2/29, P.305

22. Agnivesha. Charaka Samhita. Yadavji Trikamji Acharya, Editor. Varanasi: Chaukhamba Surbharati Prakashan; 2013. Shareer Sthana 3/7, P.310). C. Prakriti: Vata dominant Prakriti is prone to develop the disease.

23. Agnivesha. Charaka Samhita. Yadavji Trikamji Acharya, Editor. Varanasi: Chaukhamba Surbharati Prakashan; 2013. Chikitsa Sthana 28/15-18, P.617

24. Agnivesha. Charaka Samhita. Yadavji Trikamji Acharya, Editor. Varanasi: Chaukhamba Surbharati Prakashan; 2013. Vimana Sthana 2/6, P.238

25. Srimad Vagbhat, Ashtanga Hridaya Sutrasthan, Sutra Sthan Doshadivigyaniya Adhayay 11/26-28 edited by Brahmanand Tripathi, Chaukhambha Sanskrit Pratisthan, Delhi.2003; P.88

26. Ashtang sangraha sharer sthan $2 / 54$

27. Agnivesha. Charaka Samhita. Yadavji Trikamji Acharya, Editor. Varanasi: Chaukhamba Surbharati Prakashan; 2013. Vimana Sthana 5/17, P.251

28. Vriddha Vagbhatta: Ashtangasamgraha. Sharma Shiva Prasad,Editor: Varanasi: Chaukhamba Surbharti Prakashan; 2012. Shareer Sthana 2/14, P.276

29. Agnivesha. Charaka Samhita. Yadavji Trikamji Acharya, Editor. Varanasi: Chaukhamba Surbharati Prakashan; 2013. Shareer Sthana 4/14, P.318

30. Agnivesha. Charaka Samhita. Yadavji Trikamji Acharya, Editor. 
31. Agnivesha. Charaka Samhita. Yadavji Trikamji Acharya, Editor. Varanasi: Chaukhamba Surbharati Prakashan; 2013. Vimana Sthana 6/8, P.258

32. Vagbhata-Ashtanga Hridayam with commentaries Sarvangasundara of Arunadatta and Ayurvedarasayana of Hemadri, edited by Pt. Bhisagacarya Harishastri Paradkar, Chaukhamba Surbharti Academy, Varanasi, 2000, Sutrasthana, 11/31

33. Agnivesha. Charaka Samhita. Yadavji Trikamji Acharya, Editor. Varanasi: Chaukhamba Surbharati Prakashan; 2013. Sutra Sthana 28/27

34. Sushruta Samhita, Dr. Anant Ram Sharma, Susruta Vimarsini Hindi commentary, Chaukhamba Surbharati Prakashana, Varanasi, Reprint Edition 2017, 1st volume, Sutrasthana, chapter 15 verse 12, P.118.

35. Agnivesha. Charaka Samhita. Yadavji Trikamji Acharya, Editor. Varanasi: Chaukhamba Surbharati Prakashan; 2013. Shareer Sthana 6/6, P.330

36. Agnivesha, Charaka, Dridhabala. Charaka Samhita, Siddhi Sthana, Kalpanasiddhiradhyaya 1/25. In: Tripathi B, Deshpande PJ, editors. reprint ed. Varanasi: Chaukambha Sanskrit Pratishtan; 2003. p. 1165.

37. Chattergee CC. 10th ed. Vol. 1. Calcutta: Medical Allied Agency; 1985. Human Physiology; pp. 6-36

\section{Source of Support: Nil \\ Conflict of Interest: None Declared}

How to cite this URL: Pradnya Vijay Shirke: An Ayurvedic Approach Towards Postmenopausal Osteoporosis-A Review. International Ayurvedic Medical Journal \{online\} 2021 \{cited January, 2021\} Available from: http://www.iamj.in/posts/images/upload/183_189.pdf 